Green, A. A., Lewis, L. A., and Page, I. H. (1951). Fed. Proc., 10, 191.

Groom, D., McKee, E. H., Webb, C., Grants, F. W., Fenn, V., Hudicourt, R., and Dallemand, J. (1959). Ann. intern. Med., 51, 270.

Hirschorn, K., Hirschorn, R., Fraccaro, M., and Böök, J. A. (1959). Science, 129, 716 .

Katz, L. N., Stamler, J., Pick, R. (1958). Nutrition and Atherosclerosis. Lea and Febiger, Philadelphia.

Lewis, L. A., Olmsted, F., Page, 1. H., Lawry, E. Y., Mann Stare, F. J., Hanig, M., Lauffer, M. A., Gordon, T., and Moore, F. E. (1957). Circulation, 16, 227.

Luyken, R., Luyken-Konong, F. W. M., and Van-Dam-Barker, A. W. I. (1959). Trop. geogr. Med., 11, 49.

Morris, J. N. (1960). Modern Concepts of Cardiovascular Disease, $29,625$.

(1961). Ibid., 30, 633

Robertson, W. B.' (1959). Lancet, 1, 444.

Schneckloth, R. A., Stuart, K. L., Corcoran, A. C., and Moore, F. E (1962). Amer. Heart J., 63, 607.

Sols, A. (1947). Nature (Lond.) 160, 89.

Stainer, M. W. (1953). Ibid., 171, 880.

Thomas, W. A. Blanche, J.' C., and Lee, K. T. (1957). Arch. intern. Med., 100, 423 .

Toor, M., Katchalsky, A., Agmon, J., and Allalouf, D. (1957). Lancet, 1, 1270.

Van Slyke, D. D., Phillips, R. A., Dole, V. P., Hamilton, P. R. and Archibald, R. W., (1950). J. biol. Chem., 183, 349.

Vogelpeol, L., and Schrire, V. (1955). Lancet, 2, 1108.

\section{EFFECT OF ALIMENTARY LIPAEMIA ON PLASMA FIBRINOLYTIC ACTIVITY}

\author{
BY \\ D. OGSTON, M.A., Ph.D., M.B. \\ Lecturer in Medicine, University of Aberdcen \\ AND \\ H. W. FULLERTON, M.A., M.D., F.R.C.P. \\ F.R.C.P.Ed.
}

Regius Professor of Medicine, University of Aberdeen

In view of the abundant epidemiological evidence that dietary lipids play a major part in the pathogenesis of ischaemic heart disease, several studies of the effect of dietary fat on fibrinolytic activity have been made. These studies have produced conflicting conclusions.

Using the lysis of clots made from diluted plasma or whole blood as an index of fibrinolytic activity, Greig (1956), Buckell and Elliott (1959), and Billimoria et ai. (1959) concluded that alimentary lipaemia resulting from the ingestion of animal fat was inhibitory to fibrinolysis. Neither Nitzberg et al. (1959) nor Hougie and Ayers (1960) were able to confirm this finding.

With the euglobulin lysis-time method Buckell and Elliott (1959) found no significant difference in lysistimes after fatty or non-fatty meals, while Gajewski (1961) obtained significant inhibition in patients with coronary artery disease after feeding cream and soya-bean oil.

Contradictory results have also been obtained in the comparison of the effects of animal and vegetable fat on fibrinolysis. Greig (1956) obtained no inhibition with maize oil or safflower oil, whereas Farquhar et al. (1961) found that washed chylomicrons, produced by both butter and safflower oil meals, were inhibitory to fibrinolysis.

In view of the differing conclusions reached by previous investigators a study of the effect of high-fat meals on fibrinolysis has been undertaken.

\section{Methods}

Plasma fibrinolytic activity was determined by a modification of the method of Bidwell (1953). The modifications introduced have been described (Ogston and Fullerton, 1961). Estimations of the residual fibrin were made after incubation for 4,8 , and 24 hours.

Lipaemia was estimated by measuring the optical density of the serum, using a modification of the method described by Schwartz et al. (1952). The optical density of the serum was read in a Spekker photoelectric absorptiometer using giass cuvettes with a $2-\mathrm{cm}$. light path and an Ilford Filter 602, maximum transmission 470 millimicrons. In the Tables the results are expressed as the direct reading of the optical density (O.D.).

The following meals were used in this study:

1. Animal-fat breakfast: 2 eggs, $2 \frac{1}{2}$ oz. $(70$ g.) bacon, $1-1 \frac{1}{2}$ oz. ( $28-42 \mathrm{~g}$.) butter, toast, and tea with milk and sugar. Fat content approximately $85 \mathrm{~g}$.

2. Vegetable-fat breakfast: $2 \frac{1}{2}$ oz. $(70$ g.) "alfonal" margarine. $2 \frac{1}{2} \mathrm{oz}$. $\left(70 \mathrm{~g}\right.$.) alfonal cheese, $1 \frac{1}{2}$ pints $(750 \mathrm{ml}$.) alfonal milk, toast, tea with milk and sugar. Fat content approximately $85 \mathrm{~g}$.

3. Butter-fat breakfast: $1 \frac{3}{4} \mathrm{oz}$. $(50 \mathrm{~g}$.) butter, toast, tea with milk and sugar. Fat content approximately $50 \mathrm{~g}$.

4. Low-fat breakfast: toast with marmalade, tea with milk and sugar.

All subjects were fasted for 10 hours before the fasting sample of blood was obtained about 8.30 a.m., and they were confined to bed for the duration of the experiment.

The subjects used in these experiments were male patients convalescent from a number of conditions, including pneumonia, untreated essential hypertension, myocardial infarction, and patients in whom no organic disease could be found.

\section{Results}

Most previous studies have compared fibrinolytic activity after a low-fat meal with that after a high-fat meal in the same subject on different days. This was thought to be necessary because of the diurnal increase in fibrinolysis which occurs in most subjects. For the purposes of the first part of this study it was considered that if alimentary lipaemia did not abolish this normal diurnal increase of fibrinolysis it was unlikely to exert a significant inhibitory effect on fibrinolysis. Accordingly the diurnal increase in fibrinolytic activity in a $3 \frac{1}{2}$-hour period was determined in a group of subjects after a low-fat breakfast, and this change was compared with that found in the $3 \frac{1}{2}$-hour period after meals of $85 \mathrm{~g}$. of animal fat and $85 \mathrm{~g}$. of vegetable fat in different groups of subjects.

The plasma fibrinolytic activities before and $3 \frac{1}{2}$ hours after the three meals are shown in Tables I-III and the mean differences in Table IV. It can be seen that there is little difference in the mean increase in fibrinolysis

Table I.-Plasma Fibrinolytic Activity Before and $3 \frac{1}{2}$ Hours

\begin{tabular}{|c|c|c|c|c|c|c|c|c|}
\hline \multirow{3}{*}{$\begin{array}{l}\text { Sub- } \\
\text { ject }\end{array}$} & \multicolumn{4}{|c|}{ Fasting } & \multicolumn{4}{|c|}{ After Low-fat Meal } \\
\hline & \multirow{2}{*}{$\begin{array}{l}\text { O.D. } \\
\text { Serum }\end{array}$} & \multicolumn{3}{|c|}{$\%$ Lysis After } & \multirow{2}{*}{$\underset{\text { Serum }}{\text { O.D. }}$} & \multicolumn{3}{|c|}{ \% Lysis?After } \\
\hline & & 4 hrs. & $\begin{array}{|ll|}8 & \text { hrs. }\end{array}$ & 24 hrs. & & 4 hrs. & 8 hrs. & $24 \mathrm{hrs}$. \\
\hline $\begin{array}{l}1 \\
2 \\
3 \\
4 \\
5 \\
6 \\
7 \\
8 \\
9\end{array}$ & $\begin{array}{l}0.155 \\
0.152 \\
0.167 \\
0.135 \\
0.144 \\
0.194 \\
0.177 \\
0.111 \\
0.131\end{array}$ & $\begin{array}{c}88 \cdot 5 \\
0 \\
80 \\
0 \\
0 \\
6 \cdot 5 \\
10 \\
6 \\
6.5\end{array}$ & \begin{tabular}{|l|}
100 \\
0 \\
100 \\
$10 \cdot 5$ \\
12 \\
$19 \cdot 5$ \\
$64 \cdot$ \\
$69 \cdot 5$ \\
49
\end{tabular} & $\begin{array}{l}100 \\
0 \\
100 \\
92 \cdot 5 \\
100 \\
100 \\
100 \\
100 \\
100\end{array}$ & $\begin{array}{l}0.156 \\
0.143 \\
0.174 \\
0.129 \\
0.180 \\
0.164 \\
0.162 \\
0.110 \\
0.142\end{array}$ & $\begin{array}{c}47 \\
0 \\
77 \cdot 5 \\
12 \cdot 5 \\
0 \\
5 \cdot 5 \\
96 \\
8 \\
24\end{array}$ & $\begin{array}{c}100 \\
5 \\
100 \\
34.5 \\
20 \\
51 \\
100 \\
25.5 \\
98.5\end{array}$ & \begin{tabular}{|l|}
100 \\
65 \\
100 \\
100 \\
100 \\
100 \\
100 \\
100 \\
100
\end{tabular} \\
\hline fean & $0 \cdot 152$ & 21.9 & $47 \cdot 2$ & $88 \cdot 1$ & $0 \cdot 151$ & 28.9 & $59 \cdot 4$ & $96 \cdot 1$ \\
\hline
\end{tabular}


after the low-fat, animal-fat, and vegetable-fat meals, except for the larger difference after the animal-fat breakfast at the 24-hour incubation time. This is due

TABle II.-Plasma Fibrinolytic Activity Before and $3 \frac{1}{2}$ Hours After 85 g. Animal Fat

\begin{tabular}{|c|c|c|c|c|c|c|c|c|}
\hline \multirow{3}{*}{$\begin{array}{c}\text { Sub- } \\
\text { ject }\end{array}$} & \multicolumn{4}{|c|}{ Fasting } & \multicolumn{4}{|c|}{$3 \frac{1}{2}$ Hours After Fat Meal } \\
\hline & \multirow{2}{*}{$\begin{array}{l}\text { O.D. } \\
\text { Serum }\end{array}$} & \multicolumn{3}{|c|}{$\%$ Lysis After } & \multirow{2}{*}{$\begin{array}{l}\text { O.D. } \\
\text { Serum }\end{array}$} & \multicolumn{3}{|c|}{$\%$ Lysis After } \\
\hline & & $4 \mathrm{hrs}$. & $8 \mathrm{hrs}$. & $24 \mathrm{hrs}$. & & $4 \mathrm{hrs}$. & $8 \mathrm{hrs}$. & $24 \mathrm{hrs}$. \\
\hline $\begin{array}{r}1 \\
2 \\
3 \\
4 \\
5 \\
6 \\
7 \\
8 \\
9 \\
10\end{array}$ & $\begin{array}{l}0.248 \\
0.135 \\
0.188 \\
0.222 \\
0.111 \\
0.157 \\
0.138 \\
0.186 \\
0.135 \\
0.202\end{array}$ & $\begin{array}{c}0 \\
0 \\
4 \\
38 \\
0 \\
6 \\
7 \cdot 5 \\
67 \cdot 5 \\
0 \\
18\end{array}$ & $\begin{array}{r}0 \\
4 \\
42 \\
87 \\
15 \\
24 \\
42 \\
100 \\
3 \\
91\end{array}$ & $\begin{array}{c}29 \\
19 \\
100 \\
100 \\
91 \\
100 \\
100 \\
100 \\
33 \cdot 5 \\
100\end{array}$ & $\begin{array}{l}0.477 \\
0.756 \\
1.196 \\
0.619 \\
0.832 \\
0.213 \\
0.187 \\
0.703 \\
0.197 \\
0.287\end{array}$ & $\begin{array}{r}0 \\
5 \\
15 \\
64 \\
8 \\
0 \\
27 \\
55 \\
9 \\
8\end{array}$ & $\begin{array}{r}26 \\
17 \\
81 \\
100 \\
19 \\
28 \\
93 \\
100 \\
27 \\
62\end{array}$ & $\begin{array}{c}100 \\
99 \\
100 \\
100 \\
97 \cdot 5 \\
100 \\
100 \\
100 \\
100 \\
100\end{array}$ \\
\hline Means & $0 \cdot 172$ & $14 \cdot 1$ & $40 \cdot 8$ & $77 \cdot 3$ & 0.547 & $19 \cdot 1$ & $55 \cdot 3$ & $99 \cdot 7$ \\
\hline
\end{tabular}

TABLE III.-Plasma Fibrinolytic Activity Before and $3 \frac{1}{2}$ Hours After $85 \mathrm{~g}$. Vegetable Fat

\begin{tabular}{|c|c|c|c|c|c|c|c|c|}
\hline \multirow{3}{*}{$\begin{array}{c}\text { Sub- } \\
\text { ject }\end{array}$} & \multicolumn{4}{|c|}{ Fasting } & \multicolumn{4}{|c|}{$3 \frac{1}{2}$ Hours After Fat Meal } \\
\hline & \multirow{2}{*}{$\begin{array}{l}\text { O.D. } \\
\text { Serum }\end{array}$} & \multicolumn{3}{|c|}{ \% Lysis After } & \multirow{2}{*}{ Serum } & \multicolumn{3}{|c|}{$\%$ Lysis After } \\
\hline & & 4 hrs. & $8 \mathrm{hrs}$. & 24 hrs. & & 4 hrs. & 8 hrs. & 24 hrs. \\
\hline $\begin{array}{r}1 \\
2 \\
3 \\
4 \\
5 \\
6 \\
7 \\
8 \\
9 \\
10\end{array}$ & $\begin{array}{l}0 \cdot 165 \\
0 \cdot 127 \\
0.149 \\
0.183 \\
0.167 \\
0.134 \\
0.167 \\
0.186 \\
0.172 \\
0.204\end{array}$ & $\begin{array}{c}21 \cdot 5 \\
9 \cdot 5 \\
39 \cdot 5 \\
40 \\
0 \\
6 \cdot 5 \\
18 \cdot 5 \\
3 \cdot 5 \\
10 \\
0\end{array}$ & $\begin{array}{c}94 \cdot 5 \\
47 \\
100 \\
100 \\
0 \\
30 \cdot 5 \\
89 \cdot 5 \\
39 \cdot 5 \\
73 \cdot 5 \\
8\end{array}$ & \begin{tabular}{|c|}
100 \\
100 \\
100 \\
100 \\
43 \\
100 \\
100 \\
100 \\
100 \\
85
\end{tabular} & $\begin{array}{l}0.408 \\
0.346 \\
0.365 \\
0.929 \\
0.464 \\
0.597 \\
0.403 \\
0.309 \\
0.506 \\
0.460\end{array}$ & $\begin{array}{c}24 \\
22.5 \\
21 \\
52 \\
7 \\
14 \\
7.5 \\
11.5 \\
6.5 \\
4.5\end{array}$ & $\begin{array}{c}100 \\
91.5 \\
95 \\
100 \\
49 \\
81.5 \\
74 \cdot 5 \\
49 \\
32.5 \\
55\end{array}$ & $\begin{array}{l}100 \\
100 \\
100 \\
100 \\
100 \\
100 \\
100 \\
100 \\
100 \\
100\end{array}$ \\
\hline Teans & $0 \cdot 165$ & 14.9 & $58 \cdot 3$ & $92 \cdot 8$ & 0.479 & $17 \cdot 1$ & $72 \cdot 8$ & 100 \\
\hline
\end{tabular}

to the coincidental inclusion of three subjects $(1,2$, and 9; Table II) in this group who had low fasting fibrinolytic activity.

Reference to the optical densities reveals that a significant alimentary lipaemia was produced by the high-fat meals and that there was little difference between animal and vegetable fat in this respect.

It can be seen from the individual values (Tables I-III) that some subjects had greater fibrinolytic activity before the meal than after (Table I, subjects 1 and 8 ; Table II, subjects 8 and 10 ; Table III, subjects 3,7 , and 9). It may be noted that almost all these subjects had high fasting fibrinolytic activity, which was probably due to anxiety at the initial venepuncture (Ogston et al., 1962).

\section{Effect of Butter}

In the second part of this study alimentary lipaemia was induced with $50 \mathrm{~g}$. of butter. Subjects received either $50 \mathrm{~g}$. of butter or a low-fat breakfast on the first day and the alternative meal on the second. Plasma fibrinolytic activity was estimated before and two hours after completion of each breakfast. The interval of two hours was chosen because Billimoria et al. (1959) found that fibrinolysis was inhibited at this time after a similar amount of butter. The subjects have been divided into two groups according to which meal was given on the first day. It is seen from Table VI that one subject (10) from one group ( $50 \mathrm{~g}$. of butter on first day) and from Table $V$ that four subjects $(1,3,4$, and 5) from the other showed a marked fall in fibrinolytic activity from the first to the second estimations on the first day. All these had abnormally rapid lysis

TABle IV.-Mean Plasma Fibrinolytic Activities with Mean Differences, before and $3 \frac{1}{2}$ Hours after Low-fat Meal, $85 \mathrm{~g}$. Animal Fat, and $85 \mathrm{~g}$. Vegetable Fat

\begin{tabular}{|c|c|c|c|c|c|c|c|c|c|c|}
\hline \multirow{3}{*}{ Test Meal } & \multirow{3}{*}{$\begin{array}{l}\text { No. of } \\
\text { Subjects }\end{array}$} & \multicolumn{3}{|c|}{ Fasting } & \multicolumn{3}{|c|}{$3 \frac{1}{2}$ Hours After Meal } & \multicolumn{3}{|c|}{ Difference (All Increases) } \\
\hline & & \multicolumn{3}{|c|}{$\%$ Lysis After } & \multicolumn{3}{|c|}{ \% Lysis After } & \multicolumn{3}{|c|}{$\%$ Lysis After } \\
\hline & & $4 \mathrm{hrs}$. & $8 \mathrm{hrs}$. & $24 \mathrm{hrs}$. & $4 \mathrm{hrs}$. & $8 \mathrm{hrs}$. & $24 \mathrm{hrs}$. & $4 \mathrm{hrs}$. & $8 \mathrm{hrs}$. & $24 \mathrm{hrs}$ \\
\hline $\begin{array}{l}\text { Low-fat } \\
\text { Animal-fat } \\
\text { Vegetable-fat }\end{array}$ & $\begin{array}{r}9 \\
10 \\
10\end{array}$ & $\begin{array}{l}21 \cdot 9 \\
14 \cdot 1 \\
14.9\end{array}$ & $\begin{array}{l}47 \cdot 2 \\
40 \cdot 8 \\
58 \cdot 3\end{array}$ & $\begin{array}{l}88.1 \\
77.3 \\
92.8\end{array}$ & $\begin{array}{l}28 \cdot 9 \\
19 \cdot 1 \\
17 \cdot 1\end{array}$ & $\begin{array}{l}59 \cdot 4 \\
55 \cdot 3 \\
72.8\end{array}$ & $\begin{array}{l}96 \cdot 1 \\
99 \cdot 7 \\
100\end{array}$ & $\begin{array}{l}7 \cdot 0 \\
5 \cdot 0 \\
2 \cdot 2\end{array}$ & $\begin{array}{l}12 \cdot 2 \\
14 \cdot 5 \\
14 \cdot 5\end{array}$ & $\begin{array}{r}8.0 \\
22 \cdot 4 \\
7 \cdot 2\end{array}$ \\
\hline
\end{tabular}

Table V.-Effect of Alimentary Lipaemia Produced by $50 \mathrm{~g}$. Butter on Plasma Fibrinolytic Activity (First Day Low Fat)

\begin{tabular}{|c|c|c|c|c|c|c|c|c|c|c|c|c|c|c|c|c|}
\hline \multirow{4}{*}{ Subject } & \multicolumn{8}{|c|}{ First Day (Low Fat) } & \multicolumn{8}{|c|}{ Second Day (50 g. Butter) } \\
\hline & \multirow{2}{*}{$\begin{array}{c}\text { O.D. } \\
\text { Serum }\end{array}$} & \multicolumn{3}{|c|}{$\%$ Lysis After } & \multirow{2}{*}{$\begin{array}{c}\text { O D. } \\
\text { Serum }\end{array}$} & \multicolumn{3}{|c|}{$\%$ Lysis After } & \multirow{2}{*}{$\begin{array}{l}\text { O.D. } \\
\text { Serum }\end{array}$} & \multicolumn{3}{|c|}{$\%$ Lysis After } & \multirow{2}{*}{$\begin{array}{l}\text { O.D. } \\
\text { Serum }\end{array}$} & \multicolumn{3}{|c|}{$\%$ Lysis After } \\
\hline & & $4 \mathrm{hrs}$. & $8 \mathrm{hrs}$. & $24 \mathrm{hrs}$. & & 4 hrs. & 8 hrs. & $24 \mathrm{hrs}$. & & $4 \mathrm{hrs}$. & 8 hrs. & $24 \mathrm{hrs}$. & & $4 \mathrm{hrs}$. & 8 hrs. & 24 hrs. \\
\hline & \multicolumn{4}{|c|}{ Before } & \multicolumn{4}{|c|}{2 Hours $\Lambda$ fter } & \multicolumn{4}{|c|}{ Before } & \multicolumn{4}{|c|}{2 Hours After } \\
\hline $\begin{array}{l}1 \\
2 \\
3 \\
4 \\
5 \\
6\end{array}$ & $\begin{array}{l}0.261 \\
0.172 \\
0.161 \\
0.153 \\
0.173 \\
0.110\end{array}$ & $\begin{array}{c}72 \cdot 5 \\
6 \cdot 5 \\
70 \\
28 \cdot 5 \\
54 \cdot 5 \\
11 \cdot 5\end{array}$ & $\begin{array}{c}100 \\
27 \cdot 5 \\
100 \\
100 \\
100 \\
81\end{array}$ & $\begin{array}{l}100 \\
100 \\
100 \\
100 \\
100 \\
100\end{array}$ & $\begin{array}{l}0.270 \\
0 \cdot 152 \\
0 \cdot 156 \\
0 \cdot 136 \\
0 \cdot 176 \\
0 \cdot 110\end{array}$ & $\begin{array}{c}20 \\
4 \cdot 5 \\
13 \\
11 \cdot 5 \\
4 \\
14\end{array}$ & $\begin{array}{l}95 \\
17 \\
86 \cdot 5 \\
70 \\
32 \cdot 5 \\
80 \cdot 5\end{array}$ & $\begin{array}{l}100 \\
100 \\
100 \\
100 \\
100 \\
100\end{array}$ & $\begin{array}{l}0 \cdot 272 \\
0 \cdot 194 \\
0 \cdot 177 \\
0 \cdot 178 \\
0 \cdot 202 \\
0 \cdot 113\end{array}$ & $\begin{array}{c}0 \\
12 \\
22 \cdot 5 \\
6 \\
2 \\
9\end{array}$ & $\begin{array}{c}0 \\
32 \\
84 \cdot 5 \\
57 \\
9 \\
72 \cdot 5\end{array}$ & $\begin{array}{l}28 \cdot 5 \\
100 \\
100 \\
100 \\
100 \\
100\end{array}$ & $\begin{array}{l}0.674 \\
0.379 \\
0.312 \\
0.248 \\
0.346 \\
0.372\end{array}$ & $\begin{array}{c}0 \\
6 \cdot 5 \\
15 \cdot 5 \\
2 \\
18 \cdot 5 \\
15\end{array}$ & $\begin{array}{l}0 \\
27 \cdot 5 \\
80 \\
53 \cdot 5 \\
93 \\
82\end{array}$ & $\begin{array}{r}67 \\
100 \\
100 \\
100 \\
100 \\
100\end{array}$ \\
\hline
\end{tabular}

Table VI.--Effect of Alimentary Lipaemia Produced by 50 g. Butter on Plasma Fibrinolytic Activity (First Day Butter)

\begin{tabular}{|c|c|c|c|c|c|c|c|c|c|c|c|c|c|c|c|c|}
\hline \multirow{4}{*}{ Subject } & \multicolumn{8}{|c|}{ First Day ( $50 \mathrm{~g}$. Butter) } & \multicolumn{8}{|c|}{ Second Day (Low Fat) } \\
\hline & \multirow{2}{*}{$\begin{array}{l}\text { O.D. } \\
\text { Serum }\end{array}$} & \multicolumn{3}{|c|}{$\%$ Lysis After } & \multirow{2}{*}{$\begin{array}{l}\text { O.D. } \\
\text { Serum }\end{array}$} & \multicolumn{3}{|c|}{$\%$ Lysis After } & \multirow{2}{*}{$\begin{array}{l}\text { O.D. } \\
\text { Serum }\end{array}$} & \multicolumn{3}{|c|}{$\%$ Lysis After } & \multirow{2}{*}{$\begin{array}{l}\text { O.D. } \\
\text { Serum }\end{array}$} & \multicolumn{3}{|c|}{$\%$ Lysis After } \\
\hline & & $4 \mathrm{hrs}$. & $8 \mathrm{hrs}$. & $24 \mathrm{hrs}$. & & $4 \mathrm{hrs}$. & $8 \mathrm{hrs}$. & $24 \mathrm{hrs}$. & & 4 hrs. & $8 \mathrm{hrs}$. & $24 \mathrm{hrs}$. & & 4 hrs. & $8 \mathrm{hrs}$. & $24 \mathrm{hrs}$. \\
\hline & \multicolumn{4}{|c|}{ Before } & \multicolumn{4}{|c|}{2 Hours Af.er } & \multicolumn{4}{|c|}{ Before } & \multicolumn{4}{|c|}{2 Hours After } \\
\hline $\begin{array}{r}7 \\
8 \\
9 \\
10 \\
11 \\
12\end{array}$ & $\begin{array}{l}0 \cdot 167 \\
0 \cdot 178 \\
0 \cdot 104 \\
0 \cdot 167 \\
0 \cdot 137 \\
0 \cdot 151\end{array}$ & $\begin{array}{c}6 \\
0 \\
5 \\
94 \cdot 5 \\
13 \cdot 5 \\
7\end{array}$ & $\begin{array}{l}37 \cdot 5 \\
28 \\
24 \cdot 5 \\
100 \\
72 \\
70 \cdot 5\end{array}$ & $\begin{array}{l}100 \\
100 \\
100 \\
100 \\
100 \\
100\end{array}$ & $\begin{array}{l}0.404 \\
0.553 \\
0.151 \\
0.250 \\
0.276 \\
0.301\end{array}$ & $\begin{array}{c}3 \\
10 \\
4 \\
42 \cdot 5 \\
15 \\
12\end{array}$ & $\begin{array}{c}62 \cdot 5 \\
64 \cdot 5 \\
74 \\
100 \\
82 \\
86\end{array}$ & $\begin{array}{l}100 \\
100 \\
100 \\
100 \\
109 \\
100\end{array}$ & $\begin{array}{l}0 \cdot 184 \\
0 \cdot 207 \\
0 \cdot 112 \\
0 \cdot 148 \\
0 \cdot 153 \\
0 \cdot 162\end{array}$ & $\begin{array}{c}9 \cdot 5 \\
0 \\
5 \cdot 5 \\
23 \\
8.5 \\
5 \cdot 5\end{array}$ & $\begin{array}{l}32 \cdot 5 \\
13 \\
37 \\
98 \\
64 \\
54 \cdot 5\end{array}$ & $\begin{array}{l}100 \\
77 \cdot 5 \\
100 \\
100 \\
100 \\
100\end{array}$ & $\begin{array}{l}0.163 \\
0.222 \\
0 \cdot 112 \\
0 \cdot 130 \\
0 \cdot 142 \\
0.171\end{array}$ & $\begin{array}{c}5 \cdot 5 \\
5 \\
0 \\
22 \\
12 \cdot 5 \\
9 \cdot 5\end{array}$ & $\begin{array}{l}26 \\
37 \cdot 5 \\
20 \\
93 \cdot 5 \\
61 \\
68\end{array}$ & $\begin{array}{l}100 \\
100 \\
100 \\
100 \\
100 \\
100\end{array}$ \\
\hline
\end{tabular}


initially which fell to normal or near normal levels at subsequent venepunctures. This is shown graphically in the Chart. Clinically these subjects appeared anxious
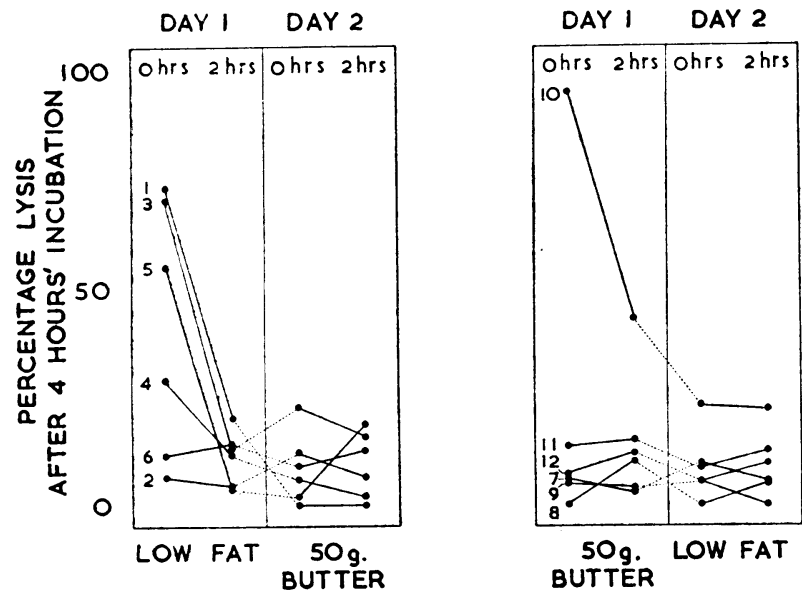

Effect of alimentary lipaemia produced by $50 \mathrm{~g}$. of butter on plasma fibrinolytic activity.

at the time of the initial venepuncture and the findings illustrate the importance of taking into consideration the effect of anxiety in causing an increase in fibrinolysis. Clearly there is no evidence from the results presented that $50 \mathrm{~g}$. of butter inhibits plasma fibrinolytic activity two hours after its ingestion. Indeed, if the effect of anxiety on the initial reading is ignored the conclusion would be that a low-fat breakfast inhibited fibrinolysis in four of the six subjects (Table V), while $50 \mathrm{~g}$. of butter produced this effect in only one out of six subjects (Table VI).

\section{Discussion}

This study has provided no evidence that alimentary lipaemia produced by $85 \mathrm{~g}$. of animal fat, $85 \mathrm{~g}$. of vegetable fat, or $50 \mathrm{~g}$. of butter inhibits fibrinolysis as measured by the lysis of diluted plasma clots. It cannot, therefore, support the hypothesis that the relationship between high-fat intakes and coronary artery disease can be explained in part by the effect of dietary fat on fibrinolysis.

It does, however, provide an example of how anxiety in the experimental subject may lead to a false interpretation of results. We have already shown that transient anxiety results in a substantial increase in fibrinolytic activity and that such anxiety is usually most prominent at the time of the first venepuncture of a series (Ogston et al., 1962). It is clear that the inclusion of a number of anxious subjects in a group who are given the test fat meal on the first day of an experiment may produce results leading to the conclusion that fat meals inhibit fibrinolysis. Few studies have stated the order in which the high-fat and low-fat meals were given, and this makes it impossible to assess the significance of some of the results reported.

\section{Summary}

The diurnal increase in plasma fibrinolytic activity found in the $3 \frac{1}{2}$-hour period after a low-fat breakfast was not significantly altered by the alimentary lipaemia produced by meals of $85 \mathrm{~g}$. of animal fat or $85 \mathrm{~g}$. of vegetable fat.

Anxiety at the time of the initial venepuncture was associated with high fibrinolytic activity. If the effect of anxiety was ignored the fall in fibrinolytic activity at subsequent venepunctures could lead to the false conclusion that the test meal had inhibited fibrinolysis.

A study of patients receiving $50 \mathrm{~g}$. of butter and a low-fat meal on alternate days showed that butterinduced lipaemia also did not affect plasma fibrinolytic activity.

We are grateful to Sister I. M. Cowie, Ward 1, Aberdeen Royal Infirmary, for help in the preparation of fat meals, and to the patients for their co-operation. We thank Alfonal Ltd. for the gift of their products.

\section{REFERENCES}

Bidwell, E. (1953). Blochem. J., 55, 497.

Billimoria, J. D., Drysdale, J., James, D. C. O., and Maclagan, N. F. (1959). Lancet, 2, 471

Buckell, M., and Elliott, F. A. (1959). Ibid., 1, 662

Farquhar, J. W. Merigan, T. C., and Sokolow, M. (1961), J. exp. Med., 113, 587.

Gajewski, J. (1961). J. Atheroscler. Res., 1, 222

Greig, H. B. W. (1956). Lancet, 2, 16.

Hougie, C., and Ayers, F. (1960). Ibid., 1, 186

Nitzberg, S., Peyman, M. A., Goldstein, R., and Proger, S. (1959). Circulation, 19, 676.

Ogston, D., and Fullerton, H. W. (1961), Lancet, 2730

- McDonald, G. A., and Fullerton, H. W. (1962). Ibid., 2, 521.

Schwartz, L., Woldow, A., and Dunsmore, R. A. (1952). J. Amer. med. Ass., 149, 364.

\section{ANTERIOR TIBIAL PAIN}

$$
\text { BY }
$$

\section{E. B. FRENCH, M.B., F.R.C.P., F.R.C.P.Ed. \\ AND \\ W. H. PRICE, B.Sc., M.B. \\ From the Eastern General Hospital, Edinburgh}

The two patients whose cases are described here suffered from a complaint which is superficially similar to the common intermittent claudication. However, by contrast they were both young men, the pain was felt over both anterior tibial regions, it was relieved by rest only after 20 to 30 minutes, there was no evidence of vascular disease, and they were cured by operation. In describing these cases to friends and colleagues it has become clear that the symptom is not rare among healthy young people, as has been noted previously (Griffiths, 1956). It may interfere with sport, and in America a condition which presents with pain of this description is known to coaches as "shin splints." "Every athletic coach is well acquainted with the tenderness and pain in the pre-tibial muscles that occurs when runners, broad-jumpers, and hikers begin to train. The affected muscles become firm and swollen" (Pearson et al., 1948). In a women's college in this country the complaint is known as "fresher's legs" (M. B. Matthews, personal communication, 1961). However, we could trace only one case in the literature which appeared to be similar to our own (Mavor, 1956).

Another condition in which pain occurs in the front of the legs is peritendinitis crepitans, but the presence of crepitus on movement is a diagnostic sign (Howard, 1937) and is not a feature of the condition discussed here.

Pain is also the presenting symptom in infarction of the anterior tibial muscles, which is known as the anterior tibial syndrome. Reports of such cases have appeared only in the last 15 years. Rarely the peroneal muscles alone may be involved (Blandy and Fuller, 1957). The literature was reviewed by Lytton and 